evening, which showed that the upper current had changed to south-east. No observations could be made during the two wet days which followed; but early in the morning of the 27 th, when the centre was about roo miles to the north, true cirri were observed moving slowly from north-east. These soon disappeared; but at $6 \mathrm{p.m}$. of the same day an important change took place, the bands of ice-cloud moving from south-south-west, from which point, or from a little west of it, the belts have continued to travel up to the time of my writing this, the lines being nearly parallel to the isobars, and to the general direction of the surface winds, and precisely resembling in character the stripes seen in most cases travelling from north-north-west when a depression, whose centre has passed a little to the north of the observer, has moved away to north-east. ${ }^{1}$

(3) In an elaborate paper in the Quart. Journ. of the R. Met. Soc. for October I 877 , the writer pointed out that in the extreme left-hand segment of an approximately circular cyclone, moving in any direction in the northern temperate latitudes, the movements of the upper currents are by no means analogous to those in the right-hand segment. ${ }^{2}$ In the case of cyclones travelling eastwards, the reason of this difference is, I think, now well understood. Owing to the great relative density of the lower atmosphere, attended with low barometric pressure, near the poles, the gradients for westerly currents are far more constant in the upper than in the lower strata of the atmosphere in the regions traversed by extra-tropical cyclones. Over a large number of these cyclones, therefore, many of the isobars in the upper regions of the atmosphere do not form closed curves, but curves somewhat resembling those which, at the earth's surface, accompanying what are popularly termed V-shaped depressions. It is a question of the utmost interest whether, during the periods in which depressions travel to the west, the distribution of gradients in the upper atmosphere is really for the time reversed, and, if so, what can be the causes of so remarkable a change. There is a further question correlated with the above, which deserves more attention than has been given to it. The writer long ago pointed out (Journ. Scot. Met. Soc., vol. iv. pp. 333335 ) that in cases of depressions travelling westward across our islands, temperatures at the earth's surface are in general higher over Scandinavia than over France; and a considerable number of instances have occurred since I 875 which have confirmed this conclusion. But in most of these cases an anticyclone has lain to the north-east of us, so that the "gradient force" of the lower strata may have tended to send the depression westwards, in addition to the ascensional force, ass ciated with condensation in the western segment, due to the indraught of relatively warm air from north and north-east. In the instance described in this paper pressure was not particularly high over Scandinavia, during the westward progress of the system, but temperature seems to have been higher, over Sweden at least, than in France.

May 30.

\section{The Crowing of the Jungle Cock.}

IN Nature (vol. xliii. p. 295) Mr. Henry O. Forbes has a letter commenting on a statement of $\mathrm{Mr}$. Bartlett to the effect that the wild jungle cock does not crow, and testifying that he once heard one. In reply, in the next number of NATURE, it was suggested that the cock heard by $\mathrm{Mr}$. Forbes was a hybrid.

I think that no one who has travelled in the jungles of Burma, during the dry season, can have any doubt that the jungle cock crows ; for he cannot fail to have heard them many times.

It so happens that, just after reading Mr. Forbes's letter, I had occasion to travel among the hills which form the watershed between the Irrawaddy and the Sittong rivers. In one region here a large kind of bamboo was seeding, so that the jungle fowl were very numerous, and I heard them crowing in great numbers. I remember one place in particular : the Karens had prepared us a hut in which to sleep just outside of their village, which consisted, like nearly all the villages in these hills, of a single house, each family having its separate room in the common

I These stripes or cirro-filum are so abundant in the rear of most depressions, towards the termination of the inversion disturbances accompanyng squalls or thunder-showers, in Europe and the Northern States that it is singularly unfortunate that the statement of an English meteorologist, to the effect that they do not exist, should have found its way into the first edition of Ferrel's "Popular Treatise on the Winds."

2 See also Ferrel, "Pup. Treat.," \$ 180 ; "Modern Meteorology," p. III (diagram).

NO. I I 29, VOL. 44] building. "At cock crowing" in the morning we had, close to us, the crowing of the village cocks, and on every side, far and near, the answering crows of multitudes of wild birds. I do not remember ever to have been treated to such a chanticleer concert before.

The idea that these wild cocks were all hybrids is inadmissible, because (I) they were so very numerous, and (2) the country is very sparsely peopled, the villages all being small and far apart, and the greater part of the country still covered with primæval forest.

The crow of the jungle cock is shrill, like that of the smallest breeds of domestic fowl, and is, perhaps, a little less prolonged than that of the average domestic cock; but it can hardly be distinguished from the crow of a small breed of fowl kept by the Karens, some individuals of which so closely resemble the wild fowl that they are used as decoys.

I have several times heard wild fowl cackle, and in this journey, while in the midst of a heavy forest, miles from any human habitation, we came upon a flock of wild fowl cackling, and could tell hy the tones that both cocks and hens were cackling. One of the followers being sent with a gun to try and get a shot, some of the birds saw him and flew, whereupon one of the cocks gave the peculiar call which the domestic cock gives when a bird flies over him.

I might add that, among the numerous birds shot in this region, there was one hen which had a pair of spurs about half an inch long.

Rangoon, May 20.

\section{Cordylophora lacustris.}

I $\mathrm{r}$ is generally believed that this tube-dwelling Hydrozoa was originally a salt-water animal, and although now found a considerable distance from tidal water, it still dwells in rivers and canals more or less connected with tidal rivers. I have for many years found it in the Chester and Ellesmere Port Canal, growing principally on the shells of the fresh-water mussel, from two to three miles from the tidal river (the Dee). It seems to be a shade-loving animal, as I have always found it under the bridges, and from 4 to 6 feet ben $3 a t h$ the surface of the water.

The tubes only remain during the winter and early spring, and the animal is fully developed in August and September. It is generally accompanied by Fredericella sultana.

King ley Lodge, Chester, June 12 . ThOMAs SHEPHEARD.

\section{Philosophical Instrument Makers.}

I FIND in your paper of June II (p. I35) that Messrs. Newton and $\mathrm{Co}$. have been appointed philosophical instrument makers to the Royal Institution of Great Britain. Allow me to state that they are not the only ones, and that I also was appointed on June I by the managers of the Royal Institution of Great Britain to be their philosophical instrument maker. I thought that in the interest of the public you should know this fact.

204 Stanhope Street, Hampstead Road, June 12. A. Hilger.

The Earthquake of June 7 .

THE earthquake of June 7 , whose centre seems to have been in the province of Verona, was also perceptible at Basle. The seismometer of the Bernoullianum Observatory registered a horizontal shock at $\mathrm{Ih} .47 \mathrm{~m}$. 29s. a. Basle mean time, which corresponds to Ih. $17 \mathrm{~m}$. Ios. Greenwich mean time.

At Thal, a village east of St. Gall, the shock was strong enough to be felt by several persons.

Basle, June I 3 .

A. RIGGENBACH-BURCKHARDT.

\section{NOTE ON EGYPTIAN IRRIGATION.}

$\mathrm{I}$ entering upon any account of Egyptian irrigation it is necessary, at first, to point out that it consists of two very broad subdivisions: (I) the irrigation effected by the Nile flood when there is rich muddy water in abundance for a land thrice as big as Egypt, and when everyone considers it his absolute right to have his fields 